\title{
Bat-Human Coronaviruses: A Global Health Problem and a Therapeutic Challenge
}

Aamir Jalal Al-Mosawi

${ }^{1}$ Advisor and expert trainer, Baghdad Medical City and the National Center of Training and Development of the Iraqi Ministry of Health

${ }^{2}$ Head, Iraq Headquarter of Copernicus Scientists International

Panel, Baghdad, Iraq

\author{
Correspondence author \\ Aamir Jalal Al-Mosawi \\ Head \\ Iraq Headquarter of Copernicus Scientists International \\ Panel \\ Baghdad \\ Iraq
}

Submitted : 14 April 2020 ; Published : 18 May 2020
Therearefourgeneraofcoronavirusesincluding $\alpha$-coronaviruses, $\beta$-coronaviruses, $\gamma$-coronaviruses, and $\delta$-coronaviruses. $\alpha$ and $\beta$-coronavirus can infect mammals, while $\gamma$-coronavirus and $\delta$-coronavirus generally infect birds. Four coronaviruses are known to cause mild upper respiratory infection in humans of all ages including infants. The transmission of coronaviruses from animals (birds) to causes respiratory illness has been reported as early as 1969 by Kapikian et al. Communitywide outbreak associated with 229E-like coronavirus has be reported as early as 1970 by Cavallaro and Monto [1-7].

Until December, 2020, two $\beta$-coronaviruses (SARS coronaviruses and MERS-coronaviruses were known to cause severe, potentially fatal pneumonia-like illness $[7,8]$.

Increasing number of cases of severe potentially fatal pneumonia caused by a new $\beta$-coronavirus was reported from Wuhan China in December 2019, and human-to-human transmission was confirmed early. On the 12th of January, 2020 the World Health Organization (WHO) officially named the condition coronavirus disease 2019 (COVID-19). The Coronavirus Study Group of the International Committee suggested naming the new coronavirus "SARS-CoV-2" [9, 10]. As of April, 2020, 13 (9 am, GMT), a total of 1,930,272 cases have been confirmed throughout the world including 119,815 deaths.

The SARS-CoV-2 which is an enveloped non-segmented positive-sense RNA virus $\beta$-coronavirus (subgenus sarbecovirus, Orthocoronavirinae subfamily), and $96.2 \%$ its genome is identical to a bat coronavirus RaTG13, and 79.5\% of its genome is simillar to SARS coronavirus. Therefore, bats have been considered a possible natural host of virus, which was possibly transmitted to a human from bats through an intermediate host. It was found that SARS-CoV-2 uses angiotensin-converting enzyme-2 (ACE2), the receptor of
SARS-CoV to infect humans $[11,12]$. In fact, bats are the natural host of a wide variety of coronaviruses including SARS-CoV-like and MERSCoV-like viruses [1, 13, 14].

Apart from supportive therapies, little evidence is available that can support a specific antiviral treatment. Antiviral drugs (oseltamivir, peramivir, zanamivir, ganciclovir, acyclovir, ribavirin monotherapy) and systemic corticosteroid are better to be avoided based on the previous experiences with treatment of coronaviruses $[15,16]$. Previous experience with treatment of coronaviruses suggested that lopinavir and ritonavir, protease inhibitors used to treat patients with human immunodeficiency virus (HIV) improved the outcome of MERS-CoV and SARS CoV patients [17-19].

The first SARS coronavirus infection was causing respiratory failure in about $20 \%$ of patients, therefore, empiric treatments were justified including protease inhibitors (lopinavir/ ritonavir) in combination with ribavirin [7, 17]. Chu et al (2004) reported the treatment of 41 patients with SARS with a combination of lopinavir/ritonavir and ribavirin. The clinical and virological outcomes were compared with 111 patients treated with ribavirin monotherapy. Poor clinical outcomes including acute respiratory distress or death were significantly lower in the lopinavir/ritonavir treated patients [17].

The experimental work of Chan et al (2015) showed that treatment with lopinavir/ritonavir or interferon$\beta 1 \mathrm{~b}$ improves outcome of MERS-CoV infection in a nonhuman primate model of common marmoset [20].

Park et al (2019) studied the efficacy of ribavirin and lopinavir/ritonavir as Post-exposure prophylaxis for healthcare workers exposed to patients with severe MERS$\mathrm{CoV}$ pre isolation pneumonia. They found that therapy 
was associated with a $40 \%$ decrease in the risk of infection without the occurrence of severe adverse effects [21].

$\beta$-coronavirus viralloads ofaCOVID-19inaKorean patientwere markedly reduced following lopinavir/ritonavir treatment [22].

Combined treatment with lopinavir/ritonavir, arbidol, and Shufeng Jiedu Capsule (SFJDC, a traditional Chinese medicine) was associated with improvement in pneumonia caused by COVID-19 [23].

Sheahan et al (2017) reported that remdesivir (GS-5734) which was developed for treatment of Ebola virus disease, can inhibit SARS-CoV and MERS-CoV replication in multiple in vitro systems, including primary human airway epithelial cell cultures with submicromolar IC50 values. According to Sheahan et al, remdesivir was also effective against bat coronaviruses, prepandemic bat coronaviruses, and circulating contemporary human $\mathrm{CoV}$ in primary human lung cells suggesting that remdesivir has broadspectrum anti-CoV activity. Sheahan et al also reported that in a mouse model of SARS-CoV early treatment with remdesivir significantly reduced lung viral load and improved clinical signs of disease and respiratory function [24]

Agostini et al (2018) reported that remdesivir effectively inhibits human and zoonotic coronaviruses in vitro and in SARS-CoV mouse model. They showed that remdesivir inhibits murine hepatitis virus (MHV) with similar 50\% effective concentration values (EC50) as SARS-CoV and MERS-CoV [25].

Brown et al showed that remdesivir has effective antiviral activity against endemic human Coronaviruses OC43 (HCoV-OC43) and 229E (HCoV-229E) with submicromolar EC50 values. They emphasized that the delta coronavirus genus have the most divergent $\mathrm{RdRp}$ as compared to SARS- and MERS-CoV and both avian and porcine members harbor a native residue in the RdRp that confers resistance in beta-Coronaviruses. However, remdesivir is highly effective against porcine delta coronavirus [26]

Remdesivir was used in the treatment of the first patient with COVID-19 in the USA and treatment was considered successful [27].

Chloroquine was thought to have an effect on SARS$\mathrm{CoV}$ infection and spread which can be attributed to immunomodulatory effects, suppression of the production/ release of TNF- $\alpha$ and IL- 6 , autophagy inhibition, and interference with the glycosylation of cellular receptors of SARS-Co. Chloroquine may act on entry and at post-entry stages of the COVID-19 infection in Vero E6 cells [28-30]. Baron et al (2020) reported teicoplanin; an antibiotic used to treat staphylococci infection which was previously reported to be effective in inhibiting the first stage of MERS-coronarivus viral cycle in human cells was also active against the SARS-Cov-2 [31].

In conclusion, the little available scientific evidence suggests that lopinavir/ritonavir, remdesivir, and teicoplanin are possibly at the top of the list weapons that have the potential to enable humans to win the fight against bat-human coronaviruses.

\section{References}

1. Kapikian AZ, James HD Jr, Kelly SJ, Dees JH, Turner $\mathrm{HC}$, et al. (1969) Isolation from man of "avian infectious bronchitis virus-like" viruses (coronaviruses) similar to $229 \mathrm{E}$ virus, with some epidemiological observations. J Infect Dis 119: 282-290.

2. Estola T (1970) Coronaviruses, a new group of animal RNA viruses. Avian Dis 14: 330-336.

3. McIntosh K, Kapikian AZ, Turner HC, Hartley JW, Parrott RH, et al. (1970) Seroepidemiologic studies of coronavirus infection in adults and children. Am J Epidemiol 91: 585592.

4. Cavallaro JJ, Monto AS (1970) Community-wide outbreak of infection with a 229E-like coronavirus in Tecumseh, Michigan. J Infect Dis 122: 272-279.

5. Hamre D, Beem M (1972) Virologic studies of acute respiratory disease in young adults. V. Coronavirus 229E infections during six years of surveillance. Am J Epidemiol 96: 94-106.

6. McIntosh K, Chao RK, Krause HE, Wasil R, Mocega HE, et al. (1974) Coronavirus infection in acute lower respiratory tract disease of infants. J Infect Dis 130: 502507.

7. Al-Mosawi AJ (2006) SARS: A new clinical syndrome. The New Iraqi Journal of Medicine 2: 25-32.

8. Yin Y, Wunderink RG (2018) MERS, SARS and other coronaviruses as causes of pneumonia. Respirology 23: 130-137.

9. Lu R, Zhao X, Li J, Niu P, Yang B, et al. (2020) Genomic characterisation and epidemiology of 2019 novel coronavirus: implications for virus origins and receptor binding. Lancet 395: 565-574.

10. Chan JF, Yuan S, Kok KH, To KK, Chu H, et al. (2020) A familial cluster of pneumonia associated with the 2019 novel coronavirus indicating person to- person transmission: a study of a family cluster. Lancet 395 : 514523.

11. Zhu N, Zhang D, Wang W, Li X, Yang B, et al. (2020) A novel coronavirus from patients with pneumonia in China, 2019. N Engl J Med 382: 727-733.

12. Zhou P, Yang XL, Wang XG, Hu B, Zhang L, et al. (2020) A pneumonia outbreak associated with a new coronavirus of probable bat origin. Nature 579: 270-273.

13. Banerjee A, Kulcsar K, Misra V, Frieman M, Mossman K (2019) Bats and coronaviruses. Viruses 11: E41.

14. Li W, Shi Z, Yu M, Ren W, Smith C, et al. (2005) Bats are natural reservoirs of SARS-like coronaviruses. Science 310: 676-679.

15. Zumla A, Chan JF, Azhar EI, Hui DS, Yuen KY (2016) Coronaviruses - drug discovery and therapeutic options. Nat Rev Drug Discov 15: 327-347.

16. Li H, Wang YM, Xu JY, Cao B (2020) Potential antiviral therapeutics for 2019 Novel Coronavirus. Chin J Tuberc 
Respir Dis 43: E002.

17. Chu CM, Cheng VC, Hung IF, Wong MM, Chan KH, et al. (2004) Role of lopinavir/ritonavir in the treatment of SARS: initial virological and clinical findings. Thorax 59: 252-256.

18. Arabi YM, Asiri AY, Assiri AM, Aziz Jokhdar HA, Alothman A, et al. (2020) Treatment of Middle East respiratory syndrome with a combination of lopinavir/ ritonavir and interferon- $\beta 1 \mathrm{~b}$ (MIRACLE trial): statistical analysis plan for a recursive two-stage group sequential randomized controlled trial. Trials 21:8.

19. Chu CM, Cheng VC, Hung IF, Wong MM, Chan KH, et al. (2004) Role of lopinavir/ritonavir in the treatment of SARS: initial virological and clinical findings. Thorax 59: 252-256.

20. Chan JF, Yao Y, Yeung ML, Deng W, Bao L, et al. (2015) Treatment With Lopinavir/Ritonavir or Interferon$\beta 1 \mathrm{~b}$ Improves Outcome of MERS-CoV Infection in a Nonhuman Primate Model of Common Marmoset. J Infect Dis 212: 1904-1913.

21. Park SY, Lee JS, Son JS, Ko JH, Peck KR, et al. (2019) Post-exposure prophylaxis for Middle East respiratory syndrome in healthcare workers. J Hosp Infect 101: 42-46.

22. Lim J, Jeon S, Shin HY, Kim MJ, Seong YM, et al. (2020) Case of the index patient who caused tertiary transmission of COVID-19 infection in Korea: the application of lopinavir/ritonavir for the treatment of COVID-19 infected pneumonia monitored by quantitative RT-PCR. J Korean Med Sci 35: e79.

23. Wang Z, Chen X, Lu Y, Chen F, Zhang W (2020) Clinical characteristics and therapeutic procedure for four cases with 2019 novel coronavirus pneumonia receiving combined Chinese and Western medicine treatment. Biosci Trends 14: 64-68.

24. Sheahan TP, Sims AC, Graham RL, Menachery VD, Gralinski LE, et al. (2017) Broad-spectrum antiviral GS5734 inhibits both epidemic and zoonotic coronaviruses. Sci Transl Med 9: eaal3653.

25. Agostini ML, Andres EL, Sims AC, Rachel L Graham, Timothy P Sheahan, et al. (2018) Coronavirus Susceptibility to the Antiviral Remdesivir (GS-5734) Is Mediated by the Viral Polymerase and the Proofreading Exoribonuclease. mBio 9: e00221-18.

26. Brown AJ, Won JJ, Graham RL, Dinnon KH 3rd, Sims AC, et al. (2019) Broad spectrum antiviral remdesivir inhibits human endemic and zoonotic deltacoronaviruses with a highly divergent RNA dependent RNA polymerase. Antiviral Res 169: 104541.

27. Holshue ML, DeBolt C, Lindquist S, Lofy KH, Wiesman J, et al. (2020) First case of 2019 novel coronavirus in the United States. N Engl J Med 382: 929-936.

28. Vincent MJ, Bergeron E, Benjannet S, Erickson BR, Rollin PE, et al. (2005) Chloroquine is a potent inhibitor of SARS coronavirus infection and spread. Virol J 2: 69.

29. Golden EB, Cho HY, Hofman FM, Louie SG, Schonthal $\mathrm{AH}$, et al. (2015) Quinoline-based antimalarial drugs: a novel class of autophagy inhibitors. Neurosurg Focus 38: E12.
30. Wang M, Cao R, Zhang L, Yang X, Liu J, et al. (2020) Remdesivir and chloroquine effectively inhibit the recently emerged novel coronavirus (2019-nCoV) in vitro. Cell Res 30: 269-271.

31. Baron SA, Devaux C, Colson P, Raoult D, Rolain JM (2020) Teicoplanin: an alternative drug for the treatment of coronavirus COVID-19? Int J Antimicrob Agents 13: 105944.
Copyright: C2020 Al Mosawi. This is an open-access article distributed under the terms of the Creative Commons Attribution License, which permits unrestricted use, distribution, and reproduction in any medium, provided the original author and source are credited. 